\title{
A Dynamic Theory of China-U.S. Trade: Making Sense of the I mbalances
}

\author{
Amar Bhidé and Edmund Phelps \\ CCS Working Paper No. 4 \\ July 2005
}

Working Papers Series

Center on Capitalism and Society

The Earth Institute at Columbia University

www. earth.columbia.edu/ccs 


\title{
A Dynamic Theory of China-U.S. Trade: Making Sense of the Imbalances
}

\author{
Amar Bhidé and Edmund Phelps ${ }^{*}$ \\ Center on Capitalism and Society, Columbia University \\ This Draft: July 16, 2005 \\ Comments Appreciated
}

\begin{abstract}
China's trade surplus with the U.S. is now more than a quarter of the U.S. trade deficit and, with China growing faster than the U.S., raises questions about its future course. Some media commentators term the chronic trade surplus "mercantilist" but offer no persuasive motive for it. Academics taking the classical static view regard the trade surpluses as a policy error. We offer a rudimentary model in which trade surplus in the early years is central for an optimal growth trajectory. The novelty derives from two features of underdevelopment shaping trade between backward economies like China and advanced economies like the U.S. First, the initial comparative disadvantages in China are an artifact of the uneven technical advances made by the U.S., so China may be able to erase those disadvantages through technological transfers bought with surpluses of exports over imports in goods and services. Reserves may be accumulated to pay for large lumps of knowhow. Second, the diffusion of new products requires learning, which takes time, so the initial dearth of familiarity in China with a range of U.S. consumer goods operates as a drag on import demand for them, which may tip trade balances into surplus.
\end{abstract}

* The authors are, respectively, Glaubinger Professor of Business and McVickar Professor of Political Economy, Columbia University, and members of Columbia's Center on Capitalism and Society. Both authors thank the Kauffman Foundation for grants that supported this research. 
\{ref.: ChinaTradeD2-16July05\}

\title{
A Dynamic Theory of China-U.S. Trade:
}

\section{Making Sense of the Imbalances}

\author{
by Amar Bhidé and Edmund S. Phelps*
}

\section{Introduction}

We offer here a dynamic theory of the trade between China and the U.S. It is focused on key roles played by technology in underdevelopment and their influence on trade and growth in the process of development. We see the trade of goods and of know-how between China and the U.S. as co-evolving, both springing from an initially wide gap in know-how between such economies. The model is fundamentally different from the classical, static comparativeadvantage model of trade in showing that the optimal growth path for China could entail trade surpluses with the U.S. and the accumulation of large foreign exchange reserves.

The present discourse does not convey an understanding of China's trade imbalances with the U.S. Two commentaries aim to explain the current account deficit of the U.S. with the rest of the world as a whole. One blames it on the outsized budgetary deficit of the U.S. The other credits it to a powerful magnetism of the U.S. economy for global investors. However, whether or not either helps to explain the U.S. current account deficit in the aggregate, neither helps to explain China's very large share of that deficit. ${ }^{1}$

Other commentators allege a kind of mercantilism in Chinese policy. In its monetarist form, China's central bank is said to prevent the appreciation of its currency that would bring its trade into balance by purchasing U.S. Treasury instruments to offset its export surplus and, in a sort of asset reflux, the inflow of direct investments by overseas companies into China. In its nonmonetary form, China is said to be the prime exemplar of a new "global saving glut" in choosing (since 1990) to save well in excess of its domestic investment needs. These two explanations tacitly assume that China's overall trade surplus must be massive but, in fact, it was only $\$ 32$ billion in $2004-$ about 2 per cent of Chinese GDP and less than 0.1 per cent of world GDP. This modest size reflects China's much smaller surplus with Europe and its

\footnotetext{
* The authors are, respectively, Glaubinger Professor of Business and McVickar Professor of Political Economy, Columbia University, and members of Columbia's Center on Capitalism and Society. Both authors thank the Kauffman Foundation for grants that supported this research.

1 Suppose that the "causes" of the U.S. trade deficit were purely U.S.-centric so that the total deficit was distributed across all other countries in proportion to their relative GDPs. According to the World Bank, the GDP of "the rest of the world" in 2003 (i.e. world GDP minus US GDP) was about 25.5 trillion. China's GDP accounted for only $6 \%$ about this amount, whereas its trade surplus with the U.S. amounted to $25 \%$ of the total U.S. trade deficit in 2003 and $26 \%$ in 2004 . In other words the US trade deficit with China is about four times its pro-rata share of the GDP of the countries that the US trades (or could trade) with.
} 
deficits with its Asian trading partners. China's mercantilism must therefore be half-hearted or somehow directed against the U.S.

The commentary also does not contain a compelling motive for China's policy. An explanation in the popular media is that China promotes exports in order to provide jobs to its surplus agricultural labor. But why would China employ a roundabout mechanism that subsidizes consumers abroad instead of, say, instituting a public works program at home? Other theories suggest that the export sector creates positive spillovers because of, for instance, the technical assistance provided by overseas customers. Although we are skeptical about the possibility, suppose that China's rulers really do believe that producing shoes and apparel for export is transformative for the Chinese economy. Why should they also save some of their export earnings? And why in the form of low-return currency reserves instead of investing them in high-return domestic projects?

From the classical Ricardian point of view, which abhors trade surpluses and the accumulation of specie, China's mercantilism is a policy mistake. But, as we see it, Ricardian models (as well as the standard theories of export led growth) fail to recognize two features of backwardness that affect trade between technologically advanced and technologically backward economies. First, the comparative advantages of the backward country are an artifact of uneven technological advances in the developed country, so that the comparative advantage of the backward country lies in the sectors where technology in the advanced country is the most rudimentary. Second, backwardness entails a paucity of consumer knowledge. Consumers in backward economies are simply unfamiliar with many of the goods made and consumed in rich countries. These include not just trendy or cutting edge items like video games but also goods like cosmetics and canned food that were once advanced but have now become commonplace in the West.

These two features lead to evolutionary rather than stationary patterns of trade. In the trade between two technically advanced countries there is no expectation of changes ahead in comparative advantages or in their demand for each others' exports. When an advanced economy trades with a backward economy, however, changes in comparative advantages occur if producers in the backward economy acquire some (if not all) of the know-how of the advanced economy. Similarly when a backward economy first opens up to trade with an advanced economy the paucity of consumer knowledge may dampen demand for some of the goods in which producers in the advanced economy have a comparative advantage. This effect gradually wears off as consumers become familiar with these goods.

Our perspective also suggests subtle trade-offs in the use of seemingly mercantilist policies by a backward economy. A surplus in its exports of goods and services over its imports allows backward countries to pay for the know-how of advanced countries. Moreover, it may be technically or contractually difficult or economically undesirable to partition know-how, so 
it may be optimal for the backward economy to save up its surpluses to buy large lumps of know-how in the future or to make payments on the debts it previously incurred for its know-how purchases. And, if underdeveloped financial markets or other institutional deficiencies hinder the accumulation of the funds necessary to purchase know-how, then the maintenance of an exchange rate that generates a trade surplus and the investment of that surplus in dollar reserves may be welfare enhancing. On the other side, the paucity of consumer knowledge in the backward country, which naturally dampens the demand for imports and tilts the trade balance to a surplus, may make such policy interventions unnecessary or even counter-productive. For example, a too low exchange rate may lead to the accumulation of more reserves than China needs for its long-run know-how purchases.

Economic modeling in recent decades that incorporates disparities in levels of development offers little precedent for the perspective of this paper, if our review of the literature has found the main contributions. The literature on trade between technological unequals typically focused on the barriers to trade between rich and poor countries. Linder (1961) showed that countries at similar stages of development trade with each other to a greater degree than they do with countries at different stages of development.

Markusen (1986) provides a model for Linder's findings in which richer countries both produce and demand more capital intensive goods. In the model by Murphy and Shleifer (1991), rich countries produce and consume goods of higher quality than do poor countries. Our model resembles Murphy and Shleifer's in that the consumption pattern in rich and poor countries are different. Yet there are noteworthy differences, which may derive from the difference in context between our respective papers. Their paper which was written in the aftermath of the collapse of the Soviet Union, provides a rationale for why producers in Eastern Europe might have nothing to sell to consumers in Western Europe (and vice versa). We are concerned with why China's exports to the U.S. are booming when its imports from the U.S. are not. Furthermore, in their model, differences in the consumption of the rich West and the poor East derive from differences in their incomes. Their representative East European consumer, like their representative Western consumer, prefers a high quality BMW but buys a low quality Lada in order to conserve her meager purchasing power. In our model, the representative consumer in China, when the country first opens up for trade, lives in a rural commune and has no prior acquaintance with cars. Until learning about cars changes her preferences, she will not buy a car of any quality or price. Also, their model makes national productivity and incomes depend just on the presumably inalienable human capital of the workforce. In our model, there are no differences in human capital and the productivity of the workforce depends just on the technologies introduced. And, in contrast to human capital, which must be indigenously accumulated, China can purchase advanced technologies from the West without thereby reducing Western productivity. 
The progenitor of our model is the model of China's economic awakening to a world of great yet uneven technical advances in Phelps (2004) and Samuelson (2004). In Phelps's story, China and the U.S. - more generally the West - were at one time alike, thus not trading partners. With the technical advances it subsequently instituted in manufacturing, the West came into possession of an artificial comparative advantage vis-à-vis China in manufacturing. Once China opens itself to trade with the West, both China and the West realize gains from classical Ricardian trade. Later, though, China's acquisition of the advanced technology from the West annihilates the comparative advantages of the trading partners and causes a return to autarky.

We extend this parable in several ways. For one thing, it does not discuss whether the Western technologies are absorbed through study and perhaps pirating or acquired through licensing or purchase; and if the latter, how China pays for the technology acquired. Here we draw on the suggestion in Bhide (2004) that the developmental significance of LDC exports lies in the wherewithal they provide for importing know-how rather than goods from developed countries. For another, we analyze how dynamics of the acquisition of know-how and of the learning by Chinese consumers of Western goods affects the evolution of trade patterns in the transitional period from the time China opens up to trade until it returns to autarky. And we discuss the challenges of formulating public policies that can help keep trade on an optimal evolutionary path.

\section{A Model of Know-how Acquisition and Trade}

We have modeled the evolution of the China trade in a spreadsheet that can be downloaded from: http://www.earthinstitute.columbia.edu/ccs/documents/china trade.xls Here we discuss just the main features and inferences of the model. As in the Murphy and Shleifer (1991) model and papers by Phelps (2004) and Samuelson (2004), we posit a world comprising two countries. We will refer to one of these countries as the U.S. but it could also represent the set of developed economies as a whole. Similarly we will refer to the other country as China but it could represent all LDCs. Both countries, that are identical in every respect, start out in a primordial state, making a variety of goods purely for their own consumption. Subsequently, thanks to its innovative entrepreneurial system, the U.S. dramatically improves its know-how for making some goods (which we call A goods) but not others (which we call B goods). In China however, more than a century of wars, revolutionary governments and isolation keep the production of all goods in the primordial way.

At the end of the extended era of backwardness, period zero, a regime change in China brings in a benevolent dictator who aims to raise Chinese living standards to a level approximating that in the U.S. To analyze the choices facing the new ruler we make the following simplifying assumptions:

We stipulate that consumers in both countries regard the basket of B goods (comprising items such as shoes and underwear) as an absolute 
necessity, and demand one basket - and only one basket - per capita per period. The basket of A goods (comprising items such as cosmetics and bottled cola drinks) is regarded as a luxury, that has utility only after the B basket has been satisfied. But, in contrast to the B basket, more A baskets provide more utility. No one values leisure (or attaches any disutility to work) and no one has any time preference for consumption. These stipulations provide a simple measure of utility: provided the demand for B goods has been satisfied, welfare increases monotonically with the consumption of A goods; and aggregate welfare over multiple periods increases with the sum of the consumption of A goods across these periods.

On the supply side we stipulate that production of both kinds of goods requires only effort, and not any capital equipment or costly raw materials. Production cannot be stockpiled -- goods must be consumed in the period in which they are produced. Labor can be used to produce A or B goods, creating the production possibility frontiers shown in Figure 1.

\section{Base case: Classical Ricardian trade.}

Suppose that in period 1 China's new ruler merely "opens up" the country to trade with the U.S. Classical Ricardian trade theory predicts that living standards in both countries will be improved if China specializes in making B goods and U.S. in making A goods. But although trading Chinesemade B goods for U.S.-made A goods improves living standards in China it does not raise them to U.S. standards unless the terms of trade are such that China receives every last bit of the gains from trade. ${ }^{2}$ Moreover transportation costs, broadly defined, limit gains from classical trade.

Although transportation costs may be small for goods such as cosmetics, for other goods such as bottled soft-drinks they can represent a significant portion of total marginal costs.

\section{$\underline{\text { Trade with interventionist import restraints }}$}

The above difficulties of catching up through classical Ricardian trade may cause China's ruler to favor trading B goods for the U.S. know-how with which to make A goods rather than for the A goods themselves. And to the extent that transportation costs exceed the economies of scale in producing for both countries, transferring know-how to China increases total welfare (i.e. the sum of A goods consumed in China and the U.S.). But how does China pay for the know-how owned by U.S. producers of A goods?

Our model assumes that the producers in the U.S. are willing to trade one basket of A goods for $\alpha$ baskets of B goods. In return for its export of the B good, China can take immediate delivery of the A goods or accumulate credits for future purchases; but, because U.S. producers don't trust China, they will not sell A goods on credit (i.e ship the A goods in one period and receive B goods in a later period). Similarly U.S. producers are willing to

\footnotetext{
${ }^{2}$ That cannot be a likely result, since China is so populous that its exports will turn the terms of trade against it.
} 
trade their entire know-how for $N$ baskets of B goods, where $(\mathrm{N}>\alpha)$ and are prepared to receive payment through credits previously accumulated by China but are unwilling to sell their know-how against future receipts of B goods.

If China's export proceeds are all used to pay for imports, there will be nothing left over to pay for know-how. China's ruler may therefore restrain imports by decreeing that some proportion of export earnings be set aside to pay for know-how purchases; we can think of this decree as an import tax or a forced saving program whose proceeds go into a know-how purchase account.

Suppose that know-how can somehow be sold on a proportionate basis - for instance if China offers $N / 2$ baskets of B goods, U.S. producers will sell advanced know-how for enough components of the A basket to halve the gap between Chinese and U.S. productivity in the basket as a whole. But, will it behoove China to acquire and use know-how on a piecemeal basis?

For expositional purposes, let us make the plausible assumption that China would immediately start using the know-how that it has paid for, rather than stockpiling the know-how for later use. Clearly, China will not purchase and use U.S. know-how, if after such a purchase it can still import A goods on better terms. Now suppose China's accumulation of credits reaches a level where domestic production of A goods becomes worthwhile. But, whereas this import substitution increases China's short term consumption of A goods, it also absorbs workers who would otherwise make B goods for export to the U.S. and thus ends any further accumulation of credits.

Therefore, in order to achieve full catch-up - and maximize the total long term consumption of China and the world - China must wait until it has accumulated the necessary $N$ credits before producing any A goods. During the periods in which this accumulation is taking place, China will run a trade and current account "surplus" with the U.S. (unless for some reason China buys and stockpiles know-how instead of credits). Then, in the single period during which China exchanges its credits for know-how, the U.S will have a large current account "surplus." Thereafter, as in the Phelps and Samuelson papers, there will be no further trade.

Notice that the number of periods of it takes for China to accumulate $N$ credits decreases monotonically with the magnitude of the import tax (i.e. higher tax rates lead to faster catch-up). Faster catch-up in turn increases China's total long-run consumption of A goods. Moreover, assuming that importing A goods from the U.S. involves at least some transportation costs, faster catch up increases overall welfare (See Figure 2). Therefore there is no conflict between the policy favored by a benevolent Chinese dictator and a social planner who favors the joint welfare of both countries - both will favor a high import tax regime. Controlling for the terms trade, a planner who wants to maximize just the U.S interests may however (depending on the values of $\alpha$ and $N$ ) favor a zero-tax regime, with no know-how transfer (i.e. continued Ricardian trade). 


\section{$\underline{\text { Trade with learning restraints }}$}

To demonstrate why import taxes may not be necessary for catch-up and could in fact be counterproductive, we will modify our assumption about Chinese demand for A type goods. Thus far we have assumed that Chinese consumers have exactly the same preferences for such goods as U.S. consumers. This may be true for some Chinese consumers. It is reasonable to believe that before China "opens up" many members of the urban elite crave Western goods that have hitherto been unavailable on unaffordable. But could there have been much pent up demand for lipstick or shampoos among the collectivized peasants in remote provinces? How many such individuals would even have encountered such products or known how to use them?

In fact, history suggests that tastes for many goods now in common use in the developed world were acquired rather than innate. Cautious consumers purchase new goods after observing the gratification of venturesome early adopters. Or they purchase only after being educated about the uses of the product by the marketing efforts of the suppliers. Sometimes the demand for new products spreads like wildfire; in other cases it may take a decade or longer. In any event it is not instantaneous.

These learning effects, we would expect, drive a wedge between the ultimate demand for the A type goods and the immediate demand when China opens up to trade. And, we can think of the initial ignorance as a natural restraint on the imports of A goods that diminishes over time. We have modeled this in our spreadsheet as follows. China starts with a low total demand for A goods when it first opens to trade. In subsequent periods, demand equals actual consumption in the prior period times a fixed learning effect. Low demand in the early periods in turn generates the trade surpluses that allow China to accumulate the credits it needs to purchase U.S. knowhow.

Relying on learning instead of taxes or tariffs to finance catch-up generates some noteworthy differences in our model. First, full catch-up does not require China to wait until it has accumulated the credits necessary to purchase the full amount of U.S. know-how. China doesn't get locked into a low level of know-how even if it starts by buying partial amounts of the know-how, because in the early periods total demand for A goods is depressed. China can satisfy all its domestic demand (for A and B goods) and still have labor available to produce B goods for export. Moreover, our model shows that if it waits, China may never be able to accumulate the credits it needs for complete know-how purchase. This is because the restraint that the learning effect imposes on imports wears off; and as it wears off, China's rate of accumulation of credits declines and may eventually become negative before it has accumulated the necessary credits. Therefore an early partial purchase may be required for full catch-up, (see Figures 3.1. and 3.2) unless, 
as in the previous case, the Chinese ruler also restrains imports through a tax or forced savings scheme.

A second noteworthy difference lies in the conflicts between the timing of know-how purchases that maximizes the welfare of China's consumers and the timing that maximizes the aggregate welfare of consumers in China and the U.S. As mentioned, in the prior case (with no learning effects) there is no conflict: given transportation costs, no matter how small, Chinese welfare and total welfare is maximized when China imposes high import taxes and purchases know-how as soon as it has accumulated the credits it needs for a full purchase of U.S. know-how. With learning effects, maximizing China's welfare entails purchasing the first installment of knowhow at the point where even the partial improvement in productivity makes it cheaper for China to make its own A goods instead of importing them. If however, total welfare is to be maximized, the Chinese purchase of know-how occurs at a later point.

Third, the learning effect does not, on its own, ensure that China will be able to afford full catch-up. In the previous case, catch-up is fast when import taxes are high, but even with low taxes China does eventually accumulate the necessary $N$ credits. If imports are restrained by learning effects rather than by taxes however, full catch-up does not occur if the rate of learning is too high or too low. If the rate of learning exceeds a threshold, all export earnings are quickly applied to importing cars, with relatively little left over to pay for know-how; and, regardless of when China starts purchasing know-how, it can never fully catch-up. Moreover, when learning rates are very fast, classical Ricardian trade (i.e. with no know-how transfer) maximizes total (China + U.S.) consumption, so even partial Chinese catch-up occurs at the expense of overall welfare. Conversely, the absence of learning, or a very slow rate of learning, limits the value China derives from the imports either of A goods or of the know-how for their manufacture; this may extinguish China's incentives to engage in any trade.

Fourth, world welfare is maximized (for non-zero transportation costs) at the top end of the learning range in which full catch-up is possible. As mentioned, if learning is extremely slow (and starts at a low enough level) the optimal outcome may be no trade, unless China is willing (or compelled) to indefinitely accumulate credits instead of receiving goods or know-how in return for its exports. If learning is fast enough to permit trade, total consumption first increases with learning rates; then, after the rate exceeds a level that precludes full catch up, total consumption declines (See Figure 4). In contrast, as we have already seen, higher import taxes (which we can think of as the analog for slow learning) always increase total consumption.

Fifth, the reversion to autarky occurs more gradually. In the previous case, China waits till it has accumulated $N$ credits and then abruptly switches its labor from exporting B goods to making A goods for domestic substitution. When learning effects are relied upon to finance know-how, we have seen that 
the purchases occur in installments, and China continues to export (at a reduced rate) after the first installment has been purchased. More intriguingly, our model suggests that China may continue to export even after it has acquired the full amount of U.S. know-how. This is because parity in know-how may be reached before China has fully learned to consume A goods. Then China may continue exporting B goods and accumulating credits for A good purchases until demand also "catches up." Then after demand has caught up trade will continue until the credits accumulated by China are offset by imports of A goods from the U.S. This final pre-autarky stage has China running trade deficits and enjoying greater prosperity than the U.S.

\section{Purchasing know-how on credit.}

So far, we assumed that the U.S. owners demand immediate payment (in B baskets or accumulated credits) for their advanced know-how. What would happen instead if U.S. producers were willing to sell their know-how on credit - i.e. transfer the know-how now against a promise of $N$ baskets of B later? We find that the welfare maximizing outcomes are remarkably similar to those we would expect under high restraints (due to tariffs or learning effects) on Chinese imports of A goods. Given non-zero transportation costs, it will be optimal for China to acquire immediately (on credit) all the know-how required for full catch-up. This would eliminate any demand for imports from the U.S. However, to repay the debt incurred to purchase the know-how China would then have to export goods to the U.S. In other words (just as with import restraints) we would observe multiple periods during which China ran trade surpluses with the U.S. and a single period during which the US would record a large current account surplus. The principal difference would be that the U.S. current account surplus would precede rather than follow its trade deficits.

Additionally, depending on the relative costs of transporting A and B goods and the rate at which China learns to consume A goods, Chinese exports might comprise A goods instead of B goods. In other words, up-front know-how transfer could lead to the U.S imports of goods that under classical Ricardian theories it would be expected to export.

\section{Policy Implications}

Our model suggests that interventionist polices which might improve living standards if policymakers had perfect foresight can be counterproductive if they do not. For instance, if learning is too fast to allow full catch-up, the Chinese ruler could use taxes (or other restraints) to tamp down on imports. In addition to allowing full catch-up for China, this 'mercantilist' intervention also may increase overall welfare. But, if learning is already in a range which permits full catch-up, interventions that further curtail imports will have the opposite effect - they reduce welfare, for China and in the aggregate. Designing an interventionist policy therefore requires knowledge of the rate of learning. But the rate of learning is difficult to 
predict or even observe; and an overestimate of the rate can lead to a welfare reducing policy.

Interventions intended to hasten learning can produce counterproductive results. For example the Chinese government may try to accelerate a rate that is too low by subsidizing the purchase of cars (e.g. by providing tax breaks to car owners). Such a policy will be welfare enhancing only if it does not push the rate of learning into the range which precludes full catch-up; and predicting whether this will occur involves a subjective judgment that is fraught with the possibility of error.

The Chinese ruler who assumes responsibility for managing the country's trade and credit balances also faces the risk of misestimating the terms of trade for imported goods and know-how. In our model we assumed that these terms were fixed. If they are not, the Chinese ruler who misestimates these terms could start purchasing know-how too early or too late, and as a consequence may end up with too few credits for full catch up or more credits than are optimal for maximizing welfare. (Although the Chinese ruler can technically correct mistakes through mid-course adjustments, as a practical matter such policy changes are difficult to implement - not the least because they may involve an admission of error. Frequent policy changes can also make it difficult for other decision makers in China to make long term plans.)

The Chinese ruler may be able to mitigate some of these risks if the U.S. producers of A goods were willing to sell their advanced know-how on credit. For instance, if U.S. producers license their know-how to a Chinese producer or if they establish a subsidiary in China that uses advanced technology, the problem of incomplete catch-up disappears. One policy mechanism to encourage such transfers is the provision of tax breaks to foreign companies. And indeed China has used this approach, levying a 15\% tax on the incomes of foreign owned firms compared to a $33 \%$ rate for domestic firms, with considerable apparent success. The effectiveness of the policy has been undermined however by the practice of "round-tripping" whereby domestic firms send capital abroad and bring it back to China in the guise of foreign investment. Anecdotal evidence also suggests that foreign investors favor projects with relatively quick payback - a preference which may have tilted the inflow of know-how towards the manufacture of export oriented B-type goods such as shoes and textiles.

The Chinese ruler can also encourage the transfer of know-how against deferred rather immediate payment through institutional interventions. For instance U.S. producers are more likely to license their know-how if they have confidence in the enforcement of their contracts with Chinese licensors. Similarly they will be more willing to transfer their know-how to their Chinese subsidiaries if they are confident about the protections afforded by the legal system to their trade secrets. But although reforms of the legal system may be necessary for confidence building, they are not sufficient. 
Confidence building also requires the passage of time. Nor can reforms of the legal system protect U.S. producers against expropriation of their know-how by the Chinese government itself. Therefore, possibly for some extended period the Chinese ruler may have to make judgments about the benefits and risks of trade related interventions.

What about the implications for U.S. policy makers? On the surface it might seem that, as discussed in Phelps (2004) and Samuelson (2004), and in contrast to classical trade theory, our model suggests a conflict between U.S. and Chinese welfare. For instance, (with learning effects and non-zero transportation costs) the speed of catch-up in our model that maximizes world consumption does not maximize U.S. consumption. As mentioned, world welfare is maximized when catch-up occurs more slowly than is optimal from China's point of view. U.S. welfare is maximized at an even slower rate (than is optimal for world welfare) or (as in the prior Phelps model) there is no catch-up at all. Thus it might seem to be in the national interest for U.S. policy makers to resist or even try to thwart the measures that China's ruler might take to hasten the acquisition and use of U.S. know-how.

Notice however that our model contains some crucial simplifying assumptions: U.S. know-how remains frozen after China opens up and the U.S. 'consumes' its entire share of the gains from trade while China 'saves' at least some of its share to purchase know-how. This is an expositionally convenient but somewhat implausible stipulation. It is more realistic to assume that U.S entrepreneurs will continue innovating after China opens up, possibly to develop entirely new kinds of A goods. In fact the rate of innovation may increase if U.S. entrepreneurs have access to some of the additional resources that become available because of trade.

Moreover China doesn't have to buy the know-how it needs to improve its productivity. It's plausible that whatever institutional constraints precluded Chinese entrepreneurs from developing know-how under the old regime may be eased or removed by the new regime. Therefore if China is prevented or discouraged from purchasing U.S. know-how, Chinese entrepreneurs may develop know-how on their own. This reinvention is not only socially wasteful, it may also reduce the earnings of U.S. exporters of goods and know-how and perhaps also reduce the rate of development of new know-how. Therefore policies that directly or indirectly discourage Chinese purchases of U.S. know-how may harm long-run standards of living in both countries.

An extension of our model suggests a counter-intuitive consequence of the pressure on U.S. policy makers exerted by U.S. workers whose interests might be injured by imports from China. Our model assumed that labor can be freely transferred between the production of A and B goods. Suppose instead that workers producing B goods in the U.S. cannot be redeployed and that their incomes are diminished by imports from China. The conventional 
story is that lobbying by B workers to curtail imports through tariffs and quotas reduces welfare. But there is also a subtle alternative possibility.

Notice that the U.S. production of B goods increases with the speed of China's catch-up in A goods (because fast catch-up quickly annihilates its comparative advantage in B goods). Therefore workers in the B goods industry should favor at least some policies (e.g. weak intellectual property protections for Western know-how or high tariffs in China on the import of A goods) that lead to faster catch-up than would suit the overall U.S. interest. But as mentioned, the overall U.S. interest may favor slower catch-up than is optimal for the world as a whole. In other words, the interests of U.S. workers in the B industry may be more closely aligned than the national interest with overall welfare than is commonly believed. ${ }^{3}$

Finally, our analysis suggests caution on the part of U.S. policy makers in relying on trade data to make inferences about the extent of Chinese protectionism or the health of the U.S economy. Tariffs and import quotas clearly are unambiguously protectionist. But, the question of whether China's fixed exchange rate is protectionist cannot be easily resolved by examining the size of its trade surplus with the U.S. or its accumulation of foreign exchange reserves. Similarly U.S. trade deficits with China, or even overall, and its borrowings from Chinese and other foreign sources of capital are not necessarily an indicator of economic ill-health. The U.S. is well ahead of other large advanced economies in its per capita incomes - therefore we should expect it to serve as an exceptionally strong magnet for the import of B type goods from China and other emerging economies. And, high per capita incomes in the U.S. likely derive from high levels of innovative activity, so the country may also represent a large net source of know-how for the rest of the world. Consequently U.S. current account deficits, even of indefinite duration, do not by themselves represent a cause for alarm. (Whether these deficits can remain at current levels is a different matter however and lies outside the scope of our analysis.)

\section{Historical parallels and contrasts}

China's trade surpluses might appear to be unusual in light of the balance of payment crises suffered by many developing countries. In fact they conform to age-old patterns in trade between rich and poor countries. According to the data in Maddison (1990), from about 1840 until the start of the Second World War, exports from most countries that were considered developing after the War (with the notable exceptions of Korea and Taiwan) exceeded their imports. In most countries now considered developed however

3 Arguably, the theft or copying of U.S. know-how reduces welfare by depriving U.S. producers of the funds they could use to finance further innovations. Such an argument however supposes that finance represents a binding constraint for further innovation in the U.S. and that payments for know-how will in fact be invested in further innovation rather than consumed. 
imports exceeded exports. These net importers include Japan - a country that allegedly followed a strategy of export led growth.

The excess of exports over imports in the developing countries cannot be explained by the mercantilist policies of their rulers. Countries like India and Indonesia were colonies, and did not have the option of pursuing mercantilist policies. Yet, as Maddison's data shows, their exports exceeded their imports by a wide margin before these countries became independent. Could it be that the surpluses reflected a forcible extraction of resources from the colonies? It is true that Britain applied some of India's trade surplus to defray so-called home charges. Indian trade surpluses also resulted in the accumulation of sterling deposits which we can regard as a source of cheap loans to Britain.

There is no evidence to suggest however that British governments prevented Indian consumers from importing British-made goods or in any way discouraged British producers from exporting their wares to India. In fact according to the prevailing imperial ideology (and Marxist analyses) colonies were supposed to provide captive export markets for their European colonizers. It is also noteworthy that Korea and Taiwan ran trade deficits when they were colonies of Japan, and it is hard to believe that Japan had a greater interest in the well being of its colonies than did Britain.

But whatever imperial Japan's intentions might have been, Maddison argues that Japan was considerably more successful in industrializing its colonies and thus in producing trade deficits in Korea and Taiwan. The colonial Indian economy in contrast did not show much development. In the last half century of British rule in India (which covers roughly the same years as the period of the Japanese colonization of Korea and Taiwan) real per capita incomes actually declined (Maddison 1971).

Apparently colonial surpluses reflected a lack of economic development. Natural endowments provided classical comparative advantages in exporting agricultural produce and commodities. But their low per capita incomes and stagnant economies limited their capacity to absorb imports from European metropoles. Per capita income in India in 1900 for instance was about 4 percent of the per capita income of Great Britain. Therefore even though net imports of cloth accounted for about half of total consumption in India between 1900 and 1904 (Tomlinson 1993) the total value of Indian imports was small. Inflows of Western know-how and capital that could have raised productivity and incomes were also apparently paltry.

This is obviously not the case with China today. Imports of goods and know-how may lag exports, but they are far from moribund. China is also upgrading its know-how at rapid clip. What might explain the difference between the rapid development of China today and the stagnation of colonial India? British colonial policies were strongly oriented towards free domestic markets, free international trade and a low tax regime. Arguably the rule of 
law and the property rights were stronger under British rule in India than they are in China today. What then discouraged British companies from setting up operations in India on a scale commensurate with the potential market in India?

We speculate that one possible reason (but by no means the only or the most important one) is that technological and organizational innovations have made it much easier to transfer know-how from developed economies to technically backward countries. If our speculation is right, this has profound implications for theories of trade and development.

Ricardo formulated the now classical model of trade at a time when by modern standards, the technological frontier had not advanced much and the differences in the levels of development between the countries Ricardo was interested in were small compared to the immutable differences in their natural endowments. Subsequently, differences in development and knowhow became much more pronounced. Nevertheless to the extent that knowhow could not be easily transferred (because it was embedded in individual human capital) traditional theories, which assumed immutable comparative advantages, provided an adequate analysis. If however, comparative advantages have become more mutable and indeed trade has become a critical instrument of their change, we need theories that focus on these dynamic effects. 


\section{References}

Bhidé, A (2004) “"Missing the true significance of outsourcing” Asian Wall Street Journal, June 23, 2004.

Linder, S., (1961), An Essay on Trade and Tranformation Uppsala: Almquist and Wicksells.

Maddison (1971), Class Structure and Economic Growth: India and Pakistan since the Moghuls. London: Allen and Unwin.

Maddison (1990), "The Colonial Burden: A comparative Perspective” in M. Scott and D. Lal (eds.) Public Policy and Economic Development: Essays in honour of Ian Little, Scott, M.F. and D. Lal (eds) Oxford: Clarendon Press.

Markusen, J.R. (1986) "Explaining the Volume of Trade: An Eclectic Approach", American Economic Review 76, 1002-1011.

Murphy, K.M., and A. Shleifer (1991) "Quality and Trade” NBER working paper No. 3622. Subsequently published in the Journal of Development Economics (1997).

Phelps, E.S., (2004) "Effects of China's recent Development in the rest of the world With special attention to Latin America”, Journal of Poicy Modeling 26 (2004) 903-910.

Samuelson, P.A., (2004) "Where Ricardo and Mill Rebut and Confirm Arguments of Mainstream Economists Supporting Globalization", Journal of Economic Perspectives 18, No.3, 135-146.

Tomlinson, B.R. (1993), The Economy of Modern India, 1860-1970, Cambridge:

Cambridge University Press. p. 107. 


\section{Figure 1: Production Possibility Frontier}

\section{A goods produced}

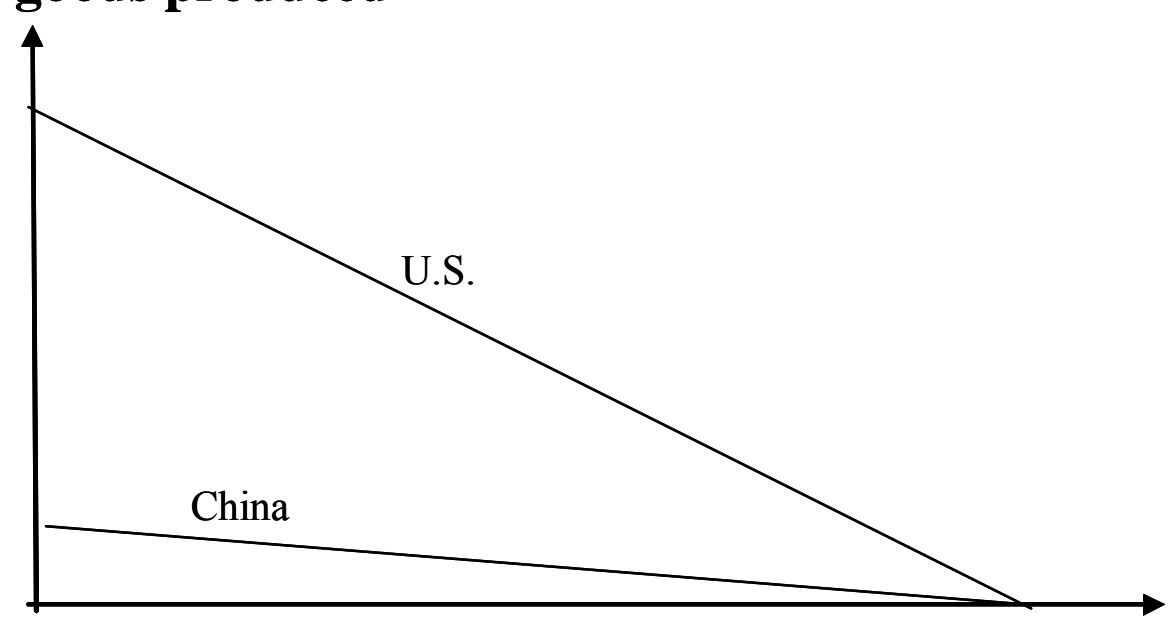

B goods produced

Figure 2: Consumption, Import Taxes and Speed of Catch-up

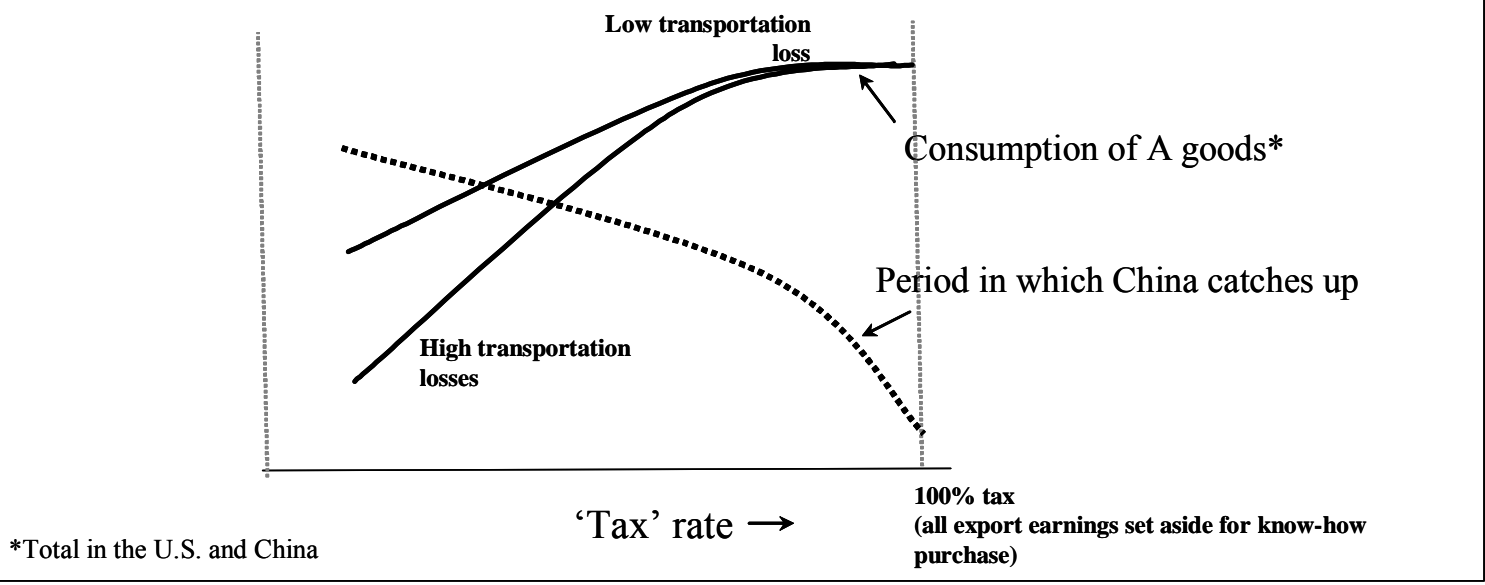



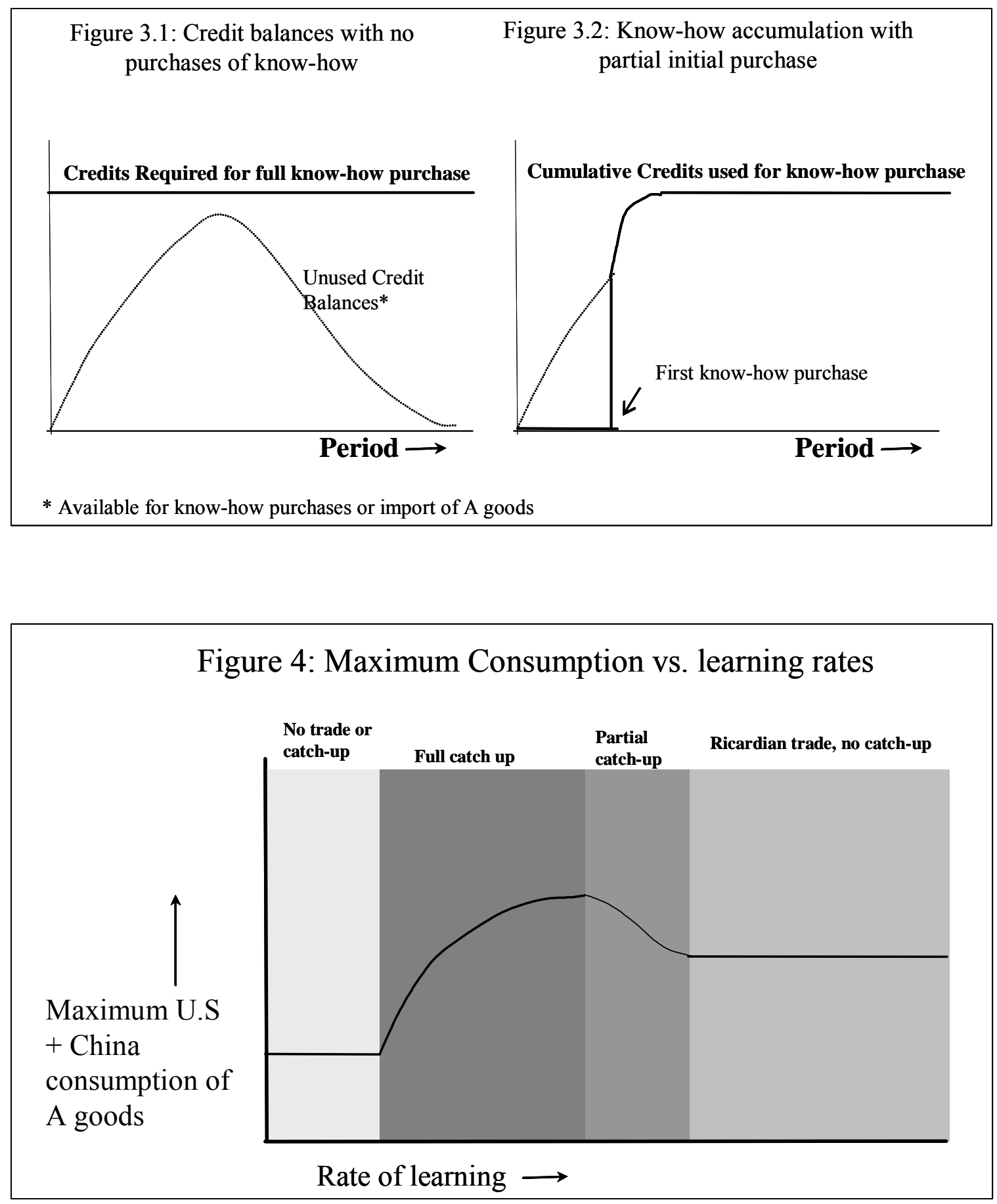